\title{
Biosystematic relationships among Psathrostachys, Critesion and Hordelymus in Hordeinae (Poaceae) based on the anatomical characteristics of leaf blades
}

\author{
Xu SU ${ }^{1,2}$, Yu-ping LIU ${ }^{3}$ and Ke-long Chen ${ }^{1,2}$ \\ ${ }^{1}$ Key Laboratory of Education Ministry of Environments and Resources in Qinghai-Tibetan Plateau, School of Geography \\ and Life Science, Qinghai Normal University, Xining 810008, China. \\ ${ }^{2}$ State Key Laboratory Breeding Base-Key Laboratory of Qinghai Province for Plateau Crop Germplasm Innovation and \\ Utilization, Qinghai University, Xining 810016, China. \\ ${ }^{3}$ Department of Ideological and Political Theory Teaching and Research, Qinghai Normal University, Xining 810008,
} China.

Accepted 10 June, 2013

\begin{abstract}
The anatomical characteristics of leaf blades of the major species of Psathyrostachys, Critesion and Hordelymus in Hordeinae were examined, their similarities and differences on the leaf blades were summarized, and the taxonomic significance of leaf anatomical features among them also were discussed. Furthermore, according to the evolutionary trends of anatomical characteristics of three genera, their evolutionary positions and relationships were inferred. The results showed that Psathyrostachys was the most primitive one among three genera, Critesion was slightly more advanced than the former, and Hordelymus was the most advanced of them; Psathyrostachys might produce immediately Critesion, whereas Hordelymus might derive immediately form Critesion. The biosystematic relationships of these three genera were corroborated by the evolutionary trend of trispikelet in the external morphology.
\end{abstract}

Key words: Critesion, Hordelymus, Psathyrostachys, biosystematic relationship, leaf anatomical characteristics.

\section{INTRODUCTION}

Psathyrostachys, Critesion and Hordelymus are three genera belonging to Hordeinae of Triticeae in Poaceae (Löve, 1984). Thereinto, Critesion was established by Rafinesque in 1819 according to Critesion jubatum (L.) Nevski (Rafinesque, 1819). It is the earliest among them and now contains 28 species. 5 species are originally found in China. Hordelymus was established by Harz in 1885 based on Hordelymus europaeus (L.) Harz described (Harz, 1885); now it only contains a type species, and was introduced by China; it is later than the former. However, Psathyrostachys was established as the latest. It was established by Nevski in 1934 according to Psathyrostachys lanuginosa (Trin.) Nevski (Nevski, 1934). At present, it contains about 10 species, 5 species originally produce in China. In the external morphology, three genera' plants all have the structural characteristics with triple-spikelet similar to Hordeum with narrowed meaning. Hence, many scholars placed some/whole species of them to the earlier Hordeum before three genera were established. Especially Critesion, some scholars still merged it into narrow Hordeum in order to form generalized Hordeum with covering more than 30 species (Chen et al., 2006). However, according to new studies from some scholars (Cai et al., 2003; Su and Cai, 2009; Su, 2009), we completely agreed with the case of independence on Critesion to distinguish with narrow Hordem of significantly different characteristics.

Certainly, it opens out the intimate relationships of three 
Table 1. Names and sources of materials for anatomical experiments.

\begin{tabular}{|c|c|c|c|c|}
\hline Genus & Species & Voucher $^{1)}$ & Locality & Experimental uses $^{2)}$ \\
\hline \multirow{4}{*}{ Psathyrostachys } & Psathyrostachys juncea (Fisch) Nevski & G. L. Fu \& R. S. Zhang 4418 HNWP & Kuitun, Xinjiang & LE, TS \\
\hline & P. huashanica Keng ex P. C. Kuo & Y. Shi, et al. 005 HNWP & Huayin, Shanxi & LE, TS \\
\hline & P. kronenburgii (Hack) Nevski & Y. H. Wu, et al. 2330 HNWP & Gonghe, Qinghai & LE, TS \\
\hline & P. lanuginosa (Trin) Nevski & Xinjiang Exp. 370 HNWP & Sailimu Lake, Xinjiang & LE \\
\hline \multirow{11}{*}{ Critesion } & Critesion bogdanii (Wilens) Á Löve & P. C. Kuo \& W. Y. Wang 045 HNWP & Dulan, Qinghai & LE, TS \\
\hline & C. bulbosum (L.) Á. Love & S. D. Yang 1 HNWP & Xining, Qinghai & TS, TS \\
\hline & C. procerum (Nevski) Á Löve & L. B. Cai 04 HNWP & Xining, Qinghai (Introduction) & LE, TS \\
\hline & C. jubatum (L.) Nevski & J. H. Li 06 HNWP & Xining, Qinghai (Introduction) & LE \\
\hline & C. roshevitzii (Bowden) L. B. Cai & B. W. Li \& H. Z. Zhang 021 HNWP & Guinan, Qinghai & LE \\
\hline & C. brevisubulatum (Trin) Á Löve & R. F. Huang 274 HNWP & Dulan, Qinghai & LE \\
\hline & C. marinum (Hudson) Á. Löve & Y. H. Sun 25 HNWP & Xining, Qinghai (Introduction) & LE \\
\hline & C. murinum (L.) Á. Löve & Y. H. Sun 12 HNWP & Xining, Qinghai (Introduction) & LE \\
\hline & C. chilense (Roem. \& Schult.) Á. Löve & L. B. Cai 011 HNWP & Xining, Qinghai (Introduction) & LE \\
\hline & C. brachyantherum (Philippi) Á. Löve & L. B. Cai 07 HNWP & Xining, Qinghai (Introduction) & LE \\
\hline & C. muticum (K. Presl) Á. Löve & L. B. Cai 03 HNWP & Xining, Qinghai (Introduction) & LE \\
\hline Hordelymus & Hordelymus europaeus (L.) Harz & Y. H. Zhou PI 531564 SAUT & Dujiangyan, Sichuan (Introduction) & LE, TS \\
\hline Bromus & Bromus inermis Layss & Z. H. Zhang, et al. 2908 HNWP & Xining, Qinghai & LE, TS \\
\hline
\end{tabular}

1) Vouchers are conserved in HNWP and SAUT. 2) LE, used for leaf epidermal observation; Ts, used in the transverse sections of leaf blades.

genera in a certain extent because they have the common characteristics of triple-spikelets. But these intimate relationships have only been expatiated on by Su and Cai (2009) based on the micromorphological characteristics of leaf epidermise and reports on them are never seen from other aspects. Thus, based on the micromorphological characteristics of epidermises and transverse sections of leaf blades, the objects of widespread species and the external morphological characteristics, we have it competitively analyzed and discussed the biosystematic relationships about three genera' plants. Its aim is to provide a useful circumstantial evidence of anatomy for the research of systematics and evolution of Triticeae.

\section{MATERIALS AND METHODS}

The vast majority of tested materials were taken from accessory herbarium specimens and a few of them were fresh plants collected in the fields. The typical vouchers of each species were shown in Table 1. The total taken materials of leaf epidermal and transverse section anatomy included 76 pieces including outgroup-Bromus inermis Layss. 5 pieces of specimens were all selected in other species except that 2 or 3 pieces of them of individual species participate in experiments. We selected 2 to 3 pieces of materials of different latitudes and altitudes in order to make repetitive experiments. Our final aim was to obtain the comprehensive understanding on variation extent of genera characteristics.

Referring to Journal of Evolutionary Biology Research Vol. 5(1): 6-20 (Su et al., 2013); terms and concepts of leaf anatomy were based on Metcalfe (Metcalfe, 1960).

\section{RESULTS}

\section{The micro-structural characteristics of leaf blades in Hordeinae}

The leaf anatomy of 16 representative species of Psathrostachys, Critesion and Hordelymus in Hordeinae were observed on the light microscope. 


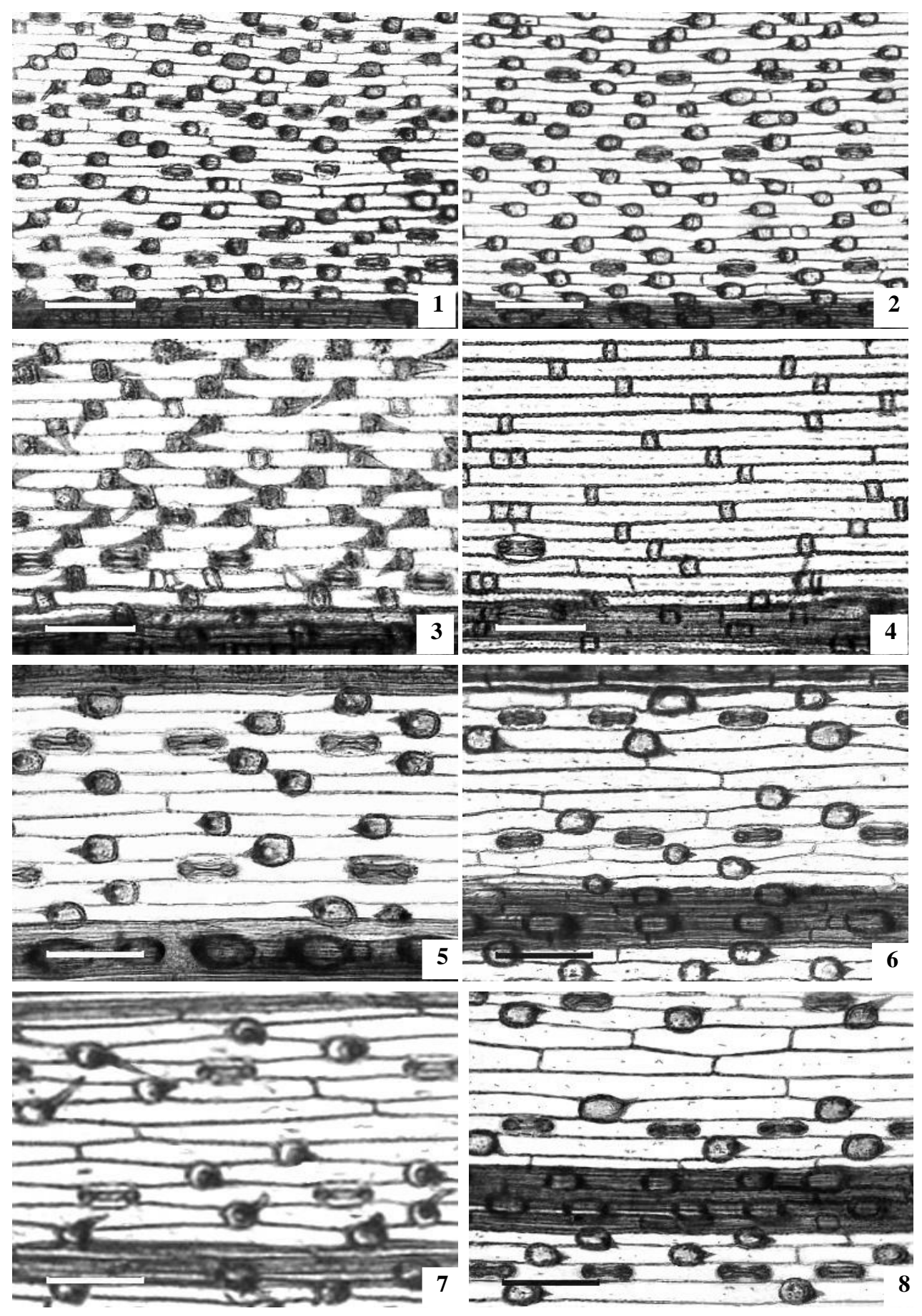

Figure 1. Light microscopic micrographs of the lower epidermises of leaf blades in 8 species of Hordeinae 1. Psathyrostachys lanuginosa; 2. P. juncea; 3. P. kronenburgii; 4. P. huashanica; 5. Critesion jubatum; 6. C. brevisubulatum; 7. C. bogdanii; 8. C. roshevitzii (scale bars in all figures indicate $100 \mu \mathrm{m})$.

The results showed that leaf epidermises (Figures 1 and 2) of three genera' plants were all consisted of long-cells, stomatal apparatus, short-cells and prickle-hairs and macro-hairs have also been found in specific taxa, while the transverse sections (Figure 3) of leaf blades were made up of epidermis, mesophyll and vascular bundle. Obviously, if according to the classification standard of grass leaf anatomy from Avdulov (1931) or Prat (1936), there is no doubt that this kind of structure style of leaf transverse sections belongs to the Festucoid type. In leaf 


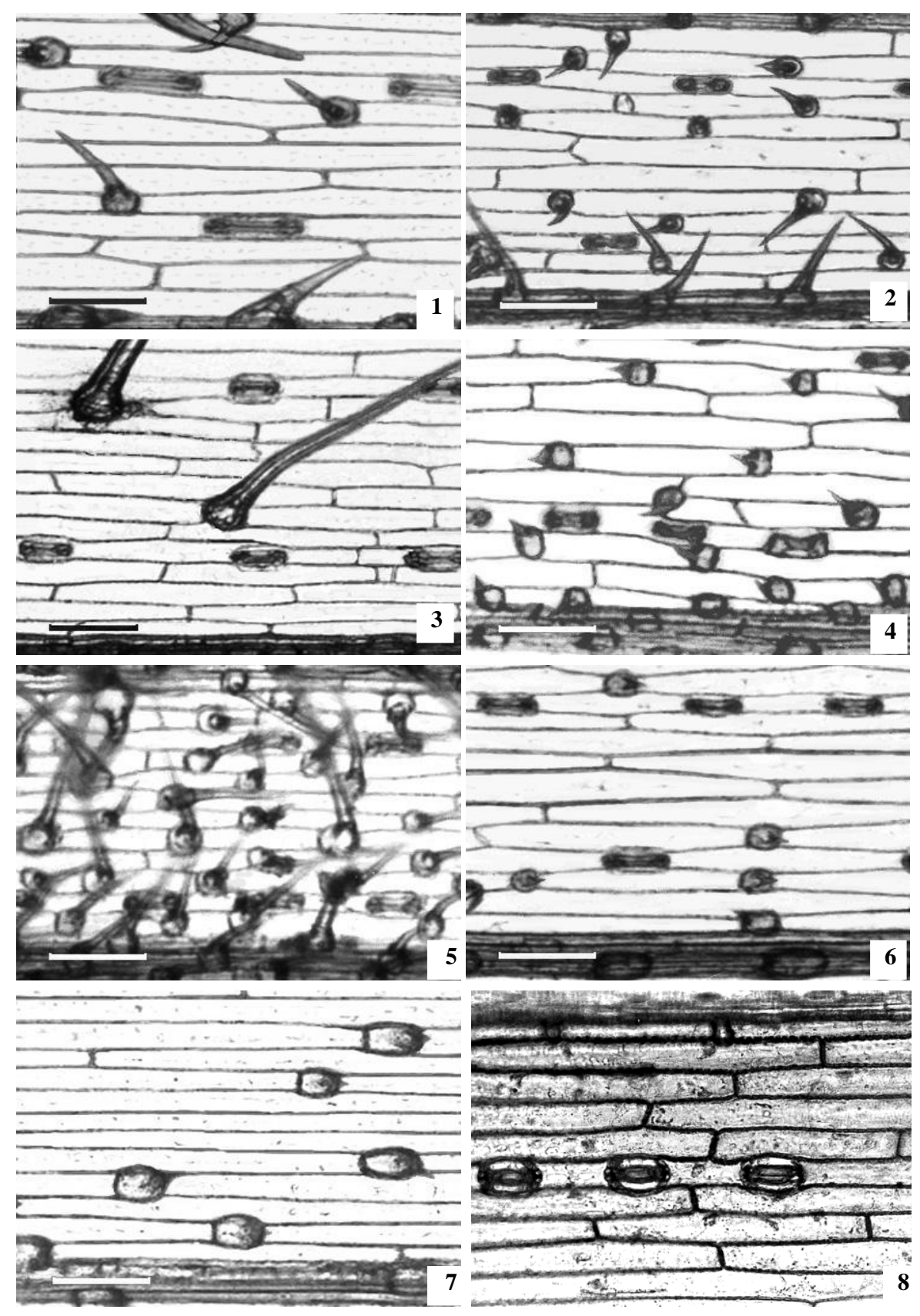

Figure 2. Light microscopic micrographs of the lower epidermises of leaf blades in 8 species of Bromus and Hordeinae. 1. C. procerum; 2. C. marinum; 3. C. murinum; 4. C. chilense; 5. C. brachyantherum; 6. C. muticum; 7. Hordelymus europaeus; 8. Bromus inermis (scale bars in all figures indicate $100 \mu \mathrm{m}$ ).

epidermal characteristics, long-cells are rectangle and cell-walls are thin and straight. Stomatal apparatus are slightly oblong/ellipse. Subsidiary cells are approximately parallel-sided or low dome-shaped. Short-cells are single and sparsely paired including prickle, hook and hook-hair. In exceptional taxa, there are macro-hairs. In transverse sections of leaf blades, the cells are smaller and epidermises are thinner around relative area of vascular bundles, while they are larger and skins are thicker. Mesophyll cell shape, magnitude and arrangement level are not very clear. It is not distinguished into palisade tissue and spongy tissue.

Vascular bundles are round or elliptic and shape of them is uneven. They have obvious double layer bundle sheath with the small inner sheath cell thickening on tangential wall and radial wall, and large outer one with 

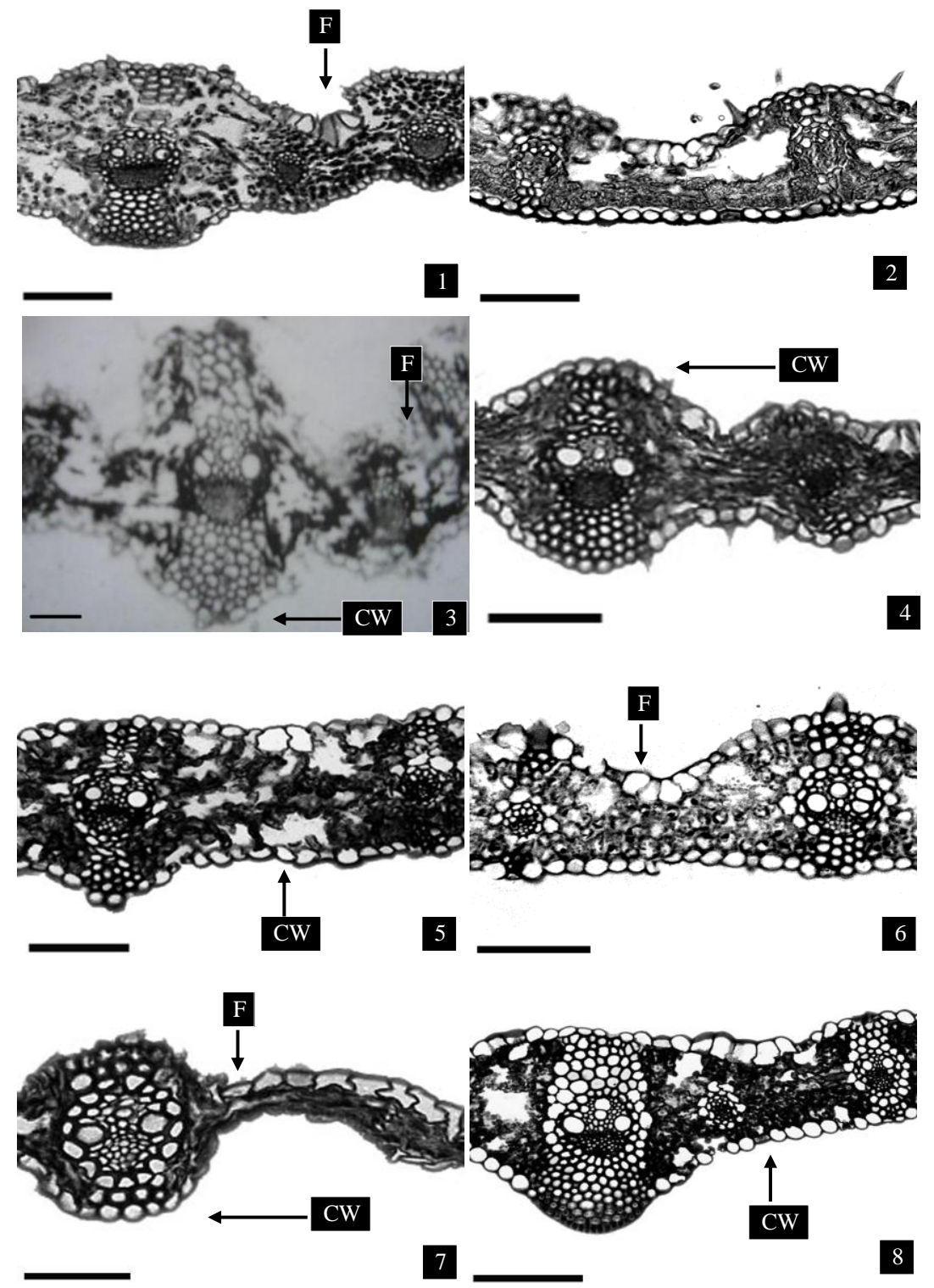

Figure 3. Light microscopic micrographs on the transverse sections of leaf blades in 8 species of Bromus and Hordeinae. 1. Psathyrostachys juncea; 2. $P$. huashanica; 3. P. kronenburgii; 4. Critesion bogdanii; 5. C. bulbosum; 6. C. procerum; 7. Hordelymus europaeus; 8 . Bromus inermis (scale bars in all figures indicate $100 \mu \mathrm{m}) \mathrm{CW}$, cell wall; F, furrow.

thin wall and sometimes having a clear chloroplast. Otherwise, the transverse sections of Bromus inermis are similar to those of Hordeinae, shape of epidermis is extremely regular and arrangement of lower epidermis is very close.

\section{The differences on micro-structure of leaf blades of three genera' plants in Hordeinae}

From Tables 2 and 3, anatomical characteristics of leaf blades are listed. The tested species have the differences with respective characters in leaf blades anatomy. They are the important foundations analyzing the relationships among species and sects in the article. As far as leaf epidermises are concerned, the differences are completely performed in several structural cells (Table 2). For example, in Psathyrostachys plants, long-cells are shorter and narrower, short-cells are sparse or universal distributing, stomata are smaller and densely distribute, subsidiary cells are low dome-shaped; while in Critesion ones, long-cells are much longer and wider, short-cells are occasionally seen, stomata are larger and sparsely distributes and subsidiary cells are often parallel-sided. 
Table 2. Comparisons of the main characteristics of lower epidermises of leaf blades in 16 species of Psathyrostachys, Critesion and Hordelymus in Hordeinae.

\begin{tabular}{|c|c|c|c|c|c|}
\hline Species & Long-cell* & Short-cell & Stoma & Prickle-hairs & Macro-hairs \\
\hline$P$. lanuginosa & 30-105 $\mu \mathrm{m}$ long, 8-13 $\mu \mathrm{m}$ wide & Infrequent, solitary & $\begin{array}{l}23-32 \mu \mathrm{m} \text { long, ca. } 12 \mu \mathrm{m} \text { wide, dense, } \\
\text { commonly with low dome-shaped subsidiary } \\
\text { cells }\end{array}$ & Small, abundant, hooked & Absent \\
\hline P. juncea & 32-130 $\mu \mathrm{m}$ long, 8-14 $\mu \mathrm{m}$ wide & Infrequent, solitary, occasionally paried & $\begin{array}{l}28-34 \mu \mathrm{m} \text { long, ca. } 14 \mu \mathrm{m} \text { wide, dense } \\
\text { commonly with low dome-shaped subsidiary } \\
\text { cells }\end{array}$ & $\begin{array}{l}\text { Small, abundant, mostly } \\
\text { hooked, infrequently prickly }\end{array}$ & Absent \\
\hline P. kronenburgii & $37-113 \mu \mathrm{m}$ long, $13-20 \mu \mathrm{m}$ wide & Infrequent, solitary, occasionally paried & $\begin{array}{l}34-41 \mu \mathrm{m} \text { long, ca. } 20 \mu \mathrm{m} \text { wide, dense, with } \\
\text { low dome-shaped subsidiary cells }\end{array}$ & Small, abundant, hooked & Absent \\
\hline P. huashanica & $83-250 \mu \mathrm{m}$ long, $14-21 \mu \mathrm{m}$ wide & Common, mostly solitary, infrequently paried & $\begin{array}{l}38-45 \mu \mathrm{m} \text { long, ca. } 23 \mu \mathrm{m} \text { wide, sparse, with } \\
\text { low dome-shaped subsidiary cells }\end{array}$ & $\begin{array}{l}\text { Small, infrequent, only } \\
\text { hooked }\end{array}$ & Absent \\
\hline C. jubatum & 90-313 $\mu \mathrm{m}$ long, $16-24 \mu \mathrm{m}$ wide & Absent or occasional, solitary & $\begin{array}{l}48-56 \mu \mathrm{m} \text { long, ca. } 24 \mu \mathrm{m} \text { wide, relatively } \\
\text { sparse, with parallel-sided subsidiary cells }\end{array}$ & $\begin{array}{l}\text { Relatively large, relatively } \\
\text { abundant, prickly and hooked }\end{array}$ & Absent \\
\hline C. brevisubulatum & $84-278 \mu \mathrm{m}$ long, $15-22 \mu \mathrm{m}$ wide & Occasional, solitary & $\begin{array}{l}38-46 \mu \mathrm{m} \text { long, ca. } 21 \mu \mathrm{m} \text { wide, relatively } \\
\text { sparse, with parallel-sided subsidiary cells }\end{array}$ & $\begin{array}{l}\text { Relatively large, relatively } \\
\text { abundant, prickly and hooked }\end{array}$ & Absent \\
\hline C. bogdanii & 98-310 $\mu \mathrm{m}$ long, $17-25 \mu \mathrm{m}$ wide & Absent or occasional, solitary & $\begin{array}{l}45-51 \mu \mathrm{m} \text { long, ca. } 21 \mu \mathrm{m} \text { wide, relatively } \\
\text { sparse, with parallel-sided subsidiary cells }\end{array}$ & $\begin{array}{l}\text { Relatively large, relatively } \\
\text { abundant, hooked or barbed }\end{array}$ & Absent \\
\hline C. roshevitzii & 95-318 $\mu \mathrm{m}$ long, $15-24 \mu \mathrm{m}$ wide & Occasional, solitary & $\begin{array}{l}40-47 \mu \mathrm{m} \text { long, ca. } 20 \mu \mathrm{m} \text { wide, relatively } \\
\text { sparse, with parallel-sided subsidiary cells }\end{array}$ & $\begin{array}{l}\begin{array}{l}\text { Relatively large, relatively } \\
\text { abundant, }\end{array} \\
\text { occasionally hooked }\end{array}$ & Absent \\
\hline C. procerum & 195-347 $\mu \mathrm{m}$ long, $18-28 \mu \mathrm{m}$ wide & Absent & $\begin{array}{l}75-87 \mu \mathrm{m} \text { long, ca. } 26 \mu \mathrm{m} \text { wide, relatively } \\
\text { sparse, with parallel-sided subsidiary cells }\end{array}$ & $\begin{array}{l}\text { Relatively large, infrequent, } \\
\text { prickly, hooked and barbed }\end{array}$ & Absent \\
\hline C. marinum & 132-349 $\mu \mathrm{m}$ long, $18-26 \mu \mathrm{m}$ wide & Absent & $\begin{array}{l}42-51 \mu \mathrm{m} \text { long, ca. } 18 \mu \mathrm{m} \text { wide, relatively } \\
\text { sparse, with parallel-sided subsidiary cells }\end{array}$ & $\begin{array}{l}\text { Relatively large, relatively } \\
\text { abundant, hooked and } \\
\text { barbed }\end{array}$ & Absent \\
\hline C. murinum & 142-358 $\mu \mathrm{m}$ long, $18-27 \mu \mathrm{m}$ wide & Absent or occasional, solitary & $\begin{array}{l}45-59 \mu \mathrm{m} \text { long, ca. } 29 \mu \mathrm{m} \text { wide, relatively } \\
\text { sparse, with slightly parallel-sided subsidiary } \\
\text { cells }\end{array}$ & $\begin{array}{l}\text { Relatively large, infrequent, } \\
\text { prickly }\end{array}$ & Present \\
\hline
\end{tabular}


Table 2. Contd.

\begin{tabular}{|c|c|c|c|c|c|}
\hline C. chilense & $85-308 \mu \mathrm{m}$ long, $18-28 \mu \mathrm{m}$ wide & Absent or occasional, solitary & $\begin{array}{l}43-52 \mu \mathrm{m} \text { long, ca. } 22 \mu \mathrm{m} \text { wide, relatively } \\
\text { sparse, with parallel-sided subsidiary cells }\end{array}$ & $\begin{array}{l}\text { Relatively large, relatively } \\
\text { abundant, mostly hooked, } \\
\text { infrequently prickly }\end{array}$ & Absent \\
\hline C. brachyantherum & 47-173 $\mu \mathrm{m}$ long, $14-21 \mu \mathrm{m}$ wide & Absent & $\begin{array}{l}40-47 \mu \mathrm{m} \text { long, ca. } 21 \mu \mathrm{m} \text { wide, relatively } \\
\text { dense, with parallel-sided subsidiary cells }\end{array}$ & $\begin{array}{l}\text { Relatively large, relatively } \\
\text { abundant, hooked or barbed }\end{array}$ & Absent \\
\hline C. muticum & $119-321 \mu \mathrm{m}$ long, $17-28 \mu \mathrm{m}$ wide & Absent & $\begin{array}{l}49-56 \mu \mathrm{m} \text { long, ca. } 22 \mu \mathrm{m} \text { wide, sparse, with } \\
\text { parallel-sided subsidiary cells }\end{array}$ & $\begin{array}{l}\text { Relatively large, infrequent, } \\
\text { prickly }\end{array}$ & Absent \\
\hline H. europaeus & $275-556 \mu \mathrm{m}$ long, $18-29 \mu \mathrm{m}$ wide & Absent & Absent & Large, infrequent, only prickly & Absent \\
\hline B. inermis & 28-89 $\mu \mathrm{m}$ long, $9-14 \mu \mathrm{m}$ wide & Sporadic, solitary & $\begin{array}{l}20-34 \mu \mathrm{m} \text { long, ca. } 13 \mu \mathrm{m} \text { wide, dense, } \\
\text { commonly with low dome-shaped subsidiary } \\
\text { cells }\end{array}$ & Small, abundant, prickly & Absent \\
\hline
\end{tabular}

* Data is expressed by the mean.

Table 3. Comparisons of the main characteristics of transverse sections of leaf blades in 8 species of Psathyrostachys, Critesion, Hordelymus and Bromus in Hordeinae.

\begin{tabular}{|c|c|c|c|c|c|c|}
\hline \multirow{2}{*}{ Species } & \multirow{2}{*}{$\begin{array}{l}\text { Thickness at midrib } \\
\text { of leaf blade }(\mu \mathrm{m})^{*}\end{array}$} & \multicolumn{2}{|c|}{ Upper epidermis } & \multicolumn{3}{|l|}{ Lower epidermis } \\
\hline & & Furrow & Rib & Furrow and rib & Cell arrangement & Thickness of cell wall \\
\hline P. juncea & 284 & Deep & Obtuse & Conspicuous & Close & Thin \\
\hline P. huashanica & 238 & Relatively deep & Obtuse & Conspicuous & Close & Thin \\
\hline P. kronenburgii & 246 & Deep & Obtuse & Relatively conspicuous & Close & Thin \\
\hline P. lanuginosa & 231 & Deep & Obtuse & Relatively conspicuous & Relatively close & thin \\
\hline C. bogdanii & 225 & Shallow & Obtuse & Relatively conspicuous & Relatively close & Relatively thin \\
\hline C. bulbosum & 197 & Relatively deep & Inconspicuous & Inconspicuous & Relatively close & Relatively thin \\
\hline C. procerum & 264 & Relatively deep & Inconspicuous & Relatively conspicuous & Relatively close & Relatively thin \\
\hline C. jubatum & 200 & Relatively deep & Inconspicuous & Relatively conspicuous & Relatively close & Relatively thin \\
\hline C. roshevitzii & 198 & Relatively deep & Inconspicuous & Relatively conspicuous & Relatively close & Relatively thin \\
\hline C. brevisubulatum & 246 & Relatively deep & Inconspicuous & Relatively conspicuous & Relatively close & Relatively thin \\
\hline H. europaeus & 232 & Shallow & Inconspicuous & Relatively conspicuous & Relax & Thick \\
\hline B. inermis & 327 & Relatively deep & Obtuse & Relatively conspicuous & Close & Thin \\
\hline
\end{tabular}

*Data is expressed by the mean. 
Table 3. Contd.

\begin{tabular}{|c|c|c|c|c|}
\hline \multirow{2}{*}{$\begin{array}{l}\text { Mesophyll } \\
\text { Thickness between the strand in middle part }(\mu \mathrm{m})\end{array}$} & \multicolumn{3}{|c|}{ Vascular bundle } & \multirow{2}{*}{ Plates } \\
\hline & Number & Midrib diameter in horizontal $(\mu \mathrm{m})$ & No. of the large vessel & \\
\hline 123 & $17-23$ & 98 & $8-11$ & Figure 3,1 \\
\hline 90 & $18-23$ & 100 & $9-12$ & Figure 3,2 \\
\hline 135 & $17-22$ & 98 & $8-11$ & Figure 3,3 \\
\hline 91 & $17-24$ & 112 & $8-14$ & Unlisted \\
\hline 89 & $17-29$ & 92 & $7-9$ & Figure 3,4 \\
\hline 135 & $18-26$ & 80 & $7-9$ & Figure 3,5 \\
\hline 118 & $19-24$ & 91 & $6-9$ & Unlisted \\
\hline 132 & $20-23$ & 87 & $8-9$ & Unlisted \\
\hline 121 & $18-25$ & 89 & $7-9$ & Unlisted \\
\hline 154 & $15-20$ & 78 & $5-7$ & Figure 3,7 \\
\hline 112 & $20-31$ & 154 & $9-13$ & Figure 3,8 \\
\hline
\end{tabular}

${ }^{*}$ Data is expressed by the mean.

Meanwhile, in point of transverse sections of leaf blades, those are performed in epidermis, mesophyll tissue and vascular bundle (Table 3 ).

In Psathrostachys plants, cell is regular, arrangement of cells is dense, the mean value of midrib diameter in horizontal is large; in Critesion ones, cell is more regular, arrangement of cells is denser, the mean value of midrib diameter in horizontal is small; while in Hordelymus ones, cell is the most regular, arrangement of cells is loose, the mean value of midrib diameter in horizontal is small. So they should belong to the obviously discontinuous and different species in anatomical characteristics.

\section{DISCUSSION}

According to the leaf anatomical characteristics of representative species from three genera' plants in
Hordeinae, it is known that two kinds of anatomical structural modality should belong to the Festucoid type by comparing with the leaf blades of the main plants anatomized in Poaceae in the past (Prat, 1932, 1936; Metcalfe, 1960; Clifford et al., 1977; Cai and Guo, 1995, 1996; Su et al., 2013). By further comparing with the previous research results, we found that they should also belong to the leaf anatomy of Triticeae below Pooideae again (Cai and Zhang, 2006; Su and Cai, 2009; Su et al., 2013). Such as observation results mentioned, there are obvious differences in anatomical structure of leaf blades in three section plants.

\section{Systematic relationships among genera and evolutionary trends of leaf blades}

If you deduce the relationships among genera with aforementioned differences, you need to make it clearer the evolutionary trend on different characteristics of each taxon. In leaf epidermal characters, the basic developmental trend and systematic relationships are in accordant with our previous result (Su and Cai, 2009). That is to say, Hordelymus can directly derive from Critesion and Psathrostachys producing Critesion. Similarly, in transverse sections of leaf blades, the characters from epidermises with obvious state grades include malformed or regular or more irregular of cell shape, thick or thin or thinner of cell-walls, lax or dense or more laxer of cell arrangement. However, the characters with regular cell-shape always exist together with those of thin cell-walls and dense cell-arrangement; those with malformed ones depend on those of thick cell-walls and relax cell-arrangement. The former is very similar to those of outgroup; while the latter is greatly different with those of outgroup. Hereby, 
we speculate that the epidermal evolutional trend should be: cell-shape is from regular to malformed, cell-wall is from thin to thick and cell-arrangement is from dense to lax. Through further research, we can also find that the aforementioned evolutionary trend is not independent. Generally, the characters with nonuniform performance and relax arrangement of epidermis are always concomitant deposit with those of small concave curvature, few numbers of the large vessels and small midrib diameter in horizontal; therefore, we think that the character having ascensivly and extrusively evolutionary trends in transverse sections of leaf blades should be that: uneven magnitude and dense arrangement and thin cell-wall of upper epidermal cells $\rightarrow$ even magnitude and lax arrangement and thick cell-wall, big concave curvature of upper epidermises $\rightarrow$ smaller concave curvature $\rightarrow$ small concave curvature, small mean value of thickness between the strand in middle part $\rightarrow$ large one, many numbers of large vessels in vascular bundles $\rightarrow$ fewer ones $\rightarrow$ few ones, large midrib diameter in horizontal $\rightarrow$ small one. Hereby, seeing the main difference of each genus, Psathrostachys should be the most primordial taxon, Critesion should be the more evolutional one than the former, while Hordelymus should be the most evolutional one among three genera.

Meantime, the taxa with closer relationship in Hordeinae should include Psathrostachys and Critesion, Critesion and Hordelymus. It is because that the former has much similarity including density of cell-arrangement, thickness of cell-wall; while the latter has similar of those concave curvature of lower eipidermis and thickening style of inner sheath cells. If seeing deriving origin among them, Psathrostachys with thin mesophyll tissue can directly produce Critesion with thick one, Hordelymus with thick cell-wall can also derive Critesion with thin one.

\section{Systematic relationships among genera and evolutionary trends of external morphological characters}

If the relationship of three genera' plants confirms to the external modality, the relationships among three genera is also very clear. If we take account of the primary characters of Psathrostachys with perennial grass and having dense and long rhizomatosae, and the secondary those of Critesion and Hordelymus with annual grass and often having sparse and no rhizomatosae, only considering the common trait of triple-spikelets, we also see their evolutional grade. The triple-spikelets of Psathrostachys all have no handle and procreate generation and there are 2 to 3 florets per spikelet; the middle spikelet of triple-spikelets of Critesion can procreate generation but it has no handle, and there is 1 to 2 floret per spikelet; while the triple-spikelets all have short handle and procreate generation or the middle spikelet is male, and there is one floret and one further reduced floret in per spikelet. According to the theory of spica in Triticeae being able to evolve from complexity to simplicity (Kuo and Wang, 1981), it is not difficult that the inflorescences of Psathrostachys, Critesion and Hordelymus must be secondary adequate variation after the location of spikelets regularly arranges. Thus, they make each spikelet of triple-spikelets owning larger placing and developmental space.

As a result, the evolutional pattern, which Psathrostachys is the most primordial taxon and Critesion does the more evolutional and Hordelymus is the most one that has formed. What is more, during the aforementioned course, Psathrostachys with no handle of triple-spikelets and having 2 to 3 florets per spikelet naturally has the close relationship with Critesion of triple-spikelet partly having handle and having 1 to 2 floret per spikelet. They have directly original relationship; while it should have far relationship with Hordelymus with having handles and only one floret in triple-spikelet, they can have indirectly deriving relationship. Meantime, Critesion lies in the middle state of characteristic evolution and serves as the transition bridge of two genera' evolution.

\section{ACKNOWLEDGEMENTS}

We gratefully acknowledge the comments and suggestions made by the reviewers and the associate editor. This research was supported by the Natural Science Fund of Qinghai Province (2011-Z-745), State Key Laboratory Breeding Base-Key Laboratory of Qinghai Province for Plateau Crop Germplasm Innovation and Utilization (2013-01), Scientific Research Fund of Ministry of Education "Chunhui Plan" (Z2010078) and the National Science Foundation of China (31260052).

\section{REFERENCES}

Avdulov NP (1931). Kario-sistematicheskoe issledovanie Semeistva Zlakor. Bull. Appl. Bot. Genet. Plant Breed Suppl. 44:1-72.

Cai LB, Guo YP (1995). Studies on constituent cells of leaf epidermis, systematics and phylogenetic path of the family Poaceae. Acta Bot. Boreal.-Occident. Sin.15(4):323-335.

Cai LB, Guo YP (1995). Studies on constituent cells of leaf epidermis, systematics and phylogenetic path of the family Poaceae (continued) Acta Bot. Boreal.-Occident. Sin. 16(1):65-72.

Cai LB, Zhang TL, Hsiao Al (2003). The circumscription and concept of Hordeum (Poaceae) based on some leaf epidermal characteristics. Israel J. Plant Sci. 51:315-320.

Cai LB, Zhang TL (2006). Genetic relationship between Leymus and its related taxa in terms of the anatomical characteristics of their leaves. Acta Bot. Boreal.-Occident. Sin. 26:537-543.

Chen SL, Zhu GH (2006). Tribe Triticeae Dumortier. In: Wu ZY, Raven $\mathrm{PH}$, Hong DY, eds. Flora of China. Beijing: Science Press, and St Louis: Missouri Botanical Garden, 22:386-444.

Clifford HT, Watson L (1977). Identifying grasses. Queensland: University of Queensland Press.

Kuo PC, Wang SJ (1981). Researches on the evolution of the inflorescence and the generic relationships of the Triticeae in China. Acta Bot. Boreal.-Occident. Sin. 1:12-19. 
Löve Á (1984). Conspectus of the Triticeae. Feddes Repertorium, 95:425-521.

Metcalfe CR (1960). Anatomy of Monocotyledons I. Gramineae. London: Oxford Clarendon Press, pp.1-713.

Nevski SA (1934). Tribe Hordeae Benth. In: Komarov VL, Roshevits RY, Shishkin BK, eds. Flora USSR. Leningrad: Academy of Science Press USSR, 2:590-728.

Prat H (1932). L'Épidermee des Graminées. Étude anatomique et systématique. Ann. Sci. Nat. Bot. 14:117-324.

Prat H (1936). La systématique des Graminées. Ann. Sci. Nat. Bot. 18:165-258

Rafinesque CS (1819). Prodrome de 20 nouveaux genres d'animaux découverts dans l'intérieur des Etas-Unis d'Amérique, durant l'année. Journal de Physique, de Chimie et d'Histoire Naturelle, 88:417-429.
Su X (2009). Studies on the systematics and evolution of Triticeae (Poaceae).Beijing: Doctoral dissertation of postgraduate school of the Chinese academy of sciences.

Su X, Cai LB (2009). The biosystematic relationships among Psathyrostachys, Critesion and Hordelymus based on the micromorphological characteristics of leaf epidermis. Bull. Bot. Res. 29:113-117.

Su X, Liu YP, Chen KL (2013). Biosystematic relationships of three sect plants in Elymus (Poaceae) based on the anatomical characteristics of leaf blades. J. Evol. Biol. Res. 5(1):6-20. 